\title{
Absorption of 4,4'-Methylenebis [2-chloroaniline] by Human Skin
}

\author{
Bruce Chin, Michael C. Tobes, and Seong S. Han \\ Department of Environmental and Industrial Health, School of Public Health, Department of \\ Internal Medicine, School of Medicine, and Departments of Oral Biology, and Anatomy and Cell \\ Biology, Schools of Dentistry and Medicine, University of Michigan, Ann Arbor. Michigan 48109
}

Received July 12, 1982

\begin{abstract}
A system was developed to measure percutaneous absorption of water-insoluble environmental agents into human skin. Percutaneous absorption of $\left.4,4^{\prime}-{ }^{4} \mathrm{C}\right]$ methylenebis $[2$ chloroaniline] (MBOCA) was measured during dry contact exposure of MBOCA with organ cultures of neonatal foreskin. Time-dependent exposures, autoradiographs, and thin-layer chromatography indicated that MBOCA was rapidly and progressively absorbed and passed through the skin without being metabolized. The transepithelial penetration of MBOCA was temperature dependent. Under certain conditions, the stratum corneum contained more MBOCA than other layers in the skin, which suggested that the stratum corneum may not be the main barrier for percutaneous absorption of MBOCA. An assessment of risk confirmed that skin exposure is a cause for concern.
\end{abstract}

\section{INTRODUCTION}

4,4'-Methylenebis[2-chloroaniline], also referred to by its acronym, MBOCA, is carcinogenic when fed to mice (Russfield et al., 1975), rats (Kommineni et al., 1979), and dogs (Stula et al., 1978) and is mutagenic in the Ames Salmonellal microsome assay (McCann et al., 1975). The chemical structure of MBOCA is given in Fig. 1.

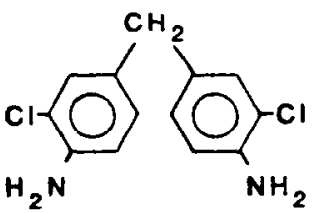

FIGURE 1

MBOCA is used as a curing agent in the manufacture of abrasion-resistant plastics, which are fabricated into gears, wheels, and tires in the automotive, aerospace, home appliance, and sporting goods industries (OSHA, 1978; Wang, 1979). This material is an environmental pollutant in Adrian, Michigan, where it was manufactured from 1971 to 1979 under the trade name Curene 442 and formulated into yellow, $\sim 0.5-\mathrm{cm}$ spheres by the Anderson Development Company. Curene 442 was reported to persist in gutters around the factory (Michigan Dept. Natural Resources, 1979), presumably because MBOCA is insoluble in water (Glowinski et al., 1978). From this source, MBOCA was disseminated radially along streets and thoroughfares to outlying areas. A sample of residential garden soil was analyzed and contained 55 ppm (Mich. Dept. Natural Resources, 1979). 
The Michigan Toxic Substance Control Commission (MTSCC) was called in to evaluate the health hazard of MBOCA in Adrian. The MTSCC constructed a model around an hypothetical 4-year-old, $15-\mathrm{kg}$ child playing in garden soil containing $55 \mathrm{ppm}$ MBOCA. Using the animal feeding data of Kommineni et al., (1979) in a series of risk assessments, Hartung (1980) calculated that the most conservative estimate was derived by extrapolation from a single-hit hypothesis: that $0.86 \mu \mathrm{g}$ MBOCA ingested/day posed a 1:100,000 risk of cancer for this individual (Table 1). Harger (1979) calculated that this hypothetical child, covered from head to toe with garden soil containing $55 \mathrm{ppm}$ MBOCA, was exposed to $1.04 \mathrm{mg}$ MBOCA in the surface film of dirt. This potentially 1000 -fold increased exposure via the skin is important since the skin is thought to be the major route of entry for MBOCA into the body (Linch et al., 1971). A measure of percutaneous absorption was necessary to complete this assessment. Percutaneous absorption is the penetration of substances from outside into the skin through the epidermis and into the dermis; substances may enter blood and lymph vessels at various levels of the dermis (Wahlberg, 1975).

In this study, a model was developed to mimic human exposures to MBOCA, by bringing dry, ${ }^{14} \mathrm{C}$-labeled MBOCA-bearing surfaces into contact with organ cultures of punch biopsies from human foreskins. Percutaneous absorption resulting from contact exposure was measured by monitoring the penetration of radioactivity into organ culture components with time. This study showed that MBOCA quickly penetrated through human neonatal foreskin. An assessment of risk revealed that intake of MBOCA through skin is two orders of magnitude higher than the ingestion estimate calculated by Hartung (1980).

\section{MATERIALS AND METHODS}

$\left[{ }^{14} \mathrm{C}\right] M B O C A$-bearing surfaces. Five microcuries of [ring $\left.{ }^{14} \mathrm{C}(\mathrm{U})\right] \mathrm{MBOCA}$ (Amersham, specific activity $10.9 \mathrm{mCi} / \mathrm{mmole}$ ) was dissolved in $2.2 \mathrm{ml} \mathrm{EtOH}$. MBOCA-bearing surfaces were prepared by drying 20- $\mu$ l aliquots of this solution on 7-mm square glass coverslips.

Tissue. Freshly taken human neonatal foreskins from Women's Hospital, University of Michigan, Ann Arbor, Michigan, were stored in Eagle's minimal essential medium (MEM) (K. C. Biologicals) at $5^{\circ} \mathrm{C}$. Organ cultures were prepared as soon as possible after circumcision, usually within $14 \mathrm{hr}$.

TABLE 1

Risk Assessments from Animal Feeding Studies: Tabulated Risk Factors for Ingested DOSES (mg/day) FOR A 15-kg, 4-YEAR-OLD CHILD

\begin{tabular}{|c|c|c|c|c|c|}
\hline \multicolumn{2}{|c|}{ Risk } & \multirow{2}{*}{$\begin{array}{c}\text { Single } \\
\text { hit }\end{array}$} & \multirow{2}{*}{$\begin{array}{c}\text { Mantel- } \\
\text { Bryan }\end{array}$} & \multirow[b]{2}{*}{ Logistic } & \multirow[b]{2}{*}{ Probit } \\
\hline$\%$ & Ratio & & & & \\
\hline 10 & $1: 10$ & 9.093 & 10.155 & 26.00 & 28.34 \\
\hline 1 & $1: 100$ & 0.867 & 0.9163 & 5.40 & 8.52 \\
\hline 0.1 & $1: 1000$ & 0.086 & 0.156 & 0.998 & 3.50 \\
\hline 0.01 & $1: 10,000$ & 0.0086 & 0.036 & 0.200 & 1.70 \\
\hline 0.001 & $1: 100,000$ & 0.00086 & 0.010 & 0.040 & 0.90 \\
\hline
\end{tabular}

Source. Hartung (1980). 
Organ culture. Subcutaneous connective tissue was removed from a foreskin, and 6-mm biopsy samples were taken with a punch (C. A. Baker) and stored in MEM to avoid dehydration. An organ culture was constructed by placing a punch biopsy, stratum corneum side up, on a moistened Gelman metricel membrane filter overlying a Falcon stainless-steel organ culture grid. The stratum corneum was wiped with a cotton swab and a dry $\left[{ }^{14} \mathrm{C}\right] \mathrm{MBOCA}$-bearing surface was applied to it. MEM $(0.4 \mathrm{ml})$ containing $10 \%$ Biocell neonatal calf serum, $10 \mu \mathrm{g}$ insulin/ $\mathrm{ml}$, and $10 \mu \mathrm{g}$ hydrocortisone/ml was deposited between the culture dish and the screen. An exploded diagram of a typical organ culture is shown in Fig. 2. Organ cultures were incubated at $37^{\circ} \mathrm{C}$ in a humidified atmosphere of $5 \% \mathrm{CO}_{2}$ in air for 1-4 hr. Since these cultures were intended to mimic dry, contact exposure to MBOCA, care was taken to avoid capillary upwelling of medium between membrane and coverslip via the tissue. Cultures which developed capillary upwelling were discarded.

At the end of the exposure period, glass, tissue, membrane, and $20 \mu \mathrm{l}$ of medium were individually transferred to separate scintillation vials. Samples were digested in NCS Amersham tissue solubilizer at $50^{\circ} \mathrm{C}$ for $24-48 \mathrm{hr}$, and counted with PCS II Amersham scintillation cocktail in a Beckman liquid scintillation counter.

Thin-layer chromatography. After exposing punch biopsies to $\left[{ }^{14} \mathrm{C}\right] \mathrm{MBOCA}$, supporting membrane filters were removed from organ cultures and individually placed into $5-\mathrm{ml}$ polypropylene tubes, and stored at $4^{\circ} \mathrm{C}$ until the time of analysis. The membrane filters were extracted with $200 \mu$ l of $100 \%$ methanol containing $25 \mu \mathrm{g}$ unlabeled $\mathrm{MBOCA} / \mathrm{ml}$ as carrier. The extract was applied onto $250 \mu \mathrm{l}$ silica gel GF Analtech glass-backed, $2.5 \times 10$-cm thin-layer chromatography plates by using an AIS multispotter. The plates were developed in benzene:acetone (4:1, $\mathrm{v} / \mathrm{v}$ ) for $11 \mathrm{~min}$ at $25^{\circ} \mathrm{C}$. The addition of carrier MBOCA to the methanol extraction solution permitted detection of MBOCA under short-wave-length uv light. MBOCA had an $R_{\mathrm{f}}$ of $0.665 \pm 0.115$. The solvent was selected so that metabolites with greater polarity than MBOCA would have $R_{f}$ 's below 0.665 and be located between MBOCA and the origin. From the origin to the solvent front, $0.5 \times 2.5$ $\mathrm{cm}$ zones of silica gel were scraped into individual liquid scintillation vials. Methanol $(0.50 \mathrm{ml})$ was added to the vials to extract the radioactivity from the silica.
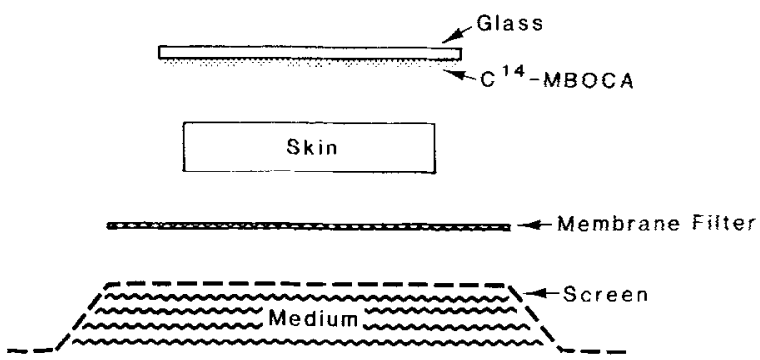

FIG. 2. Exploded schematic of organ culture, modified for studying the uptake of $\left[{ }^{14} \mathrm{C}\right] \mathrm{MBOCA}$ by human skin. 
After the addition of $10 \mathrm{ml}$ Liquidfluor-toluene scintillant, the vials were mixed and counted in a Beckman LS 7500 microprocessor-controlled liquid scintillation system. The samples were counted for $10 \mathrm{~min}$ or to a preset $2 \delta$ error of 0.50 . The recovery of radioactivity from the incubation membranes and silica gel was 87.8 and $\geqslant 98 \%$, respectively.

Radioautography. A solution was prepared by dissolving $1 \mathrm{mCi}$ of [bridge$\left.{ }^{14} \mathrm{C}\right] \mathrm{MBOCA}$ (Amersham sp act $58 \mathrm{mCi} / \mathrm{mmole}$ ) in $1 \mathrm{ml}$ of EtOH. $\left[{ }^{14} \mathrm{C}\right] \mathrm{MBOCA}$ bearing surfaces were prepared by depositing $50-\mu l$ aliquots of this solution on 7 $\mathrm{mm}$ square coverslips, which were then allowed to dry. Punch biopsies from freshly taken, neonatal foreskins were prepared for organ culture and exposed to dry $\left[{ }^{14} \mathrm{C}\right] \mathrm{MBOCA}$-bearing surfaces for $4 \mathrm{hr}$ as described above. Radioautographs were prepared from cryostat sections of exposed skin which were coated with Kodak NTB-3 nuclear track emulsion (Messier and Leblond, 1957).

To study the histology of intact foreskin, biopsy samples were fixed in $2 \%$ glutaraldehyde in $0.1 \mathrm{M}$ phosphate buffer, embedded in Epon, sectioned at $1 \mu \mathrm{m}$ thickness, stained with toluidine blue, and studied under a Zeiss microscope.

\section{RESULTS}

Time-dependent exposure studies with biopsy samples from individual foreskins demonstrated that MBOCA was rapidly absorbed and passed progressively through the skin (Table 2). In this example, the level of $\left[{ }^{14} \mathrm{C}\right] \mathrm{MBOCA}$ remaining

TABLE 2

Time Course of $\left[\mathrm{C}^{14}\right]$ MBOCA Percutaneous Penetration through Punch Biopsies from One Human NEWBorn Foreskin

\begin{tabular}{|c|c|c|c|c|c|c|c|}
\hline Sample & $\begin{array}{l}\text { Exposure } \\
\text { (hr) }\end{array}$ & $\begin{array}{c}\text { Organ } \\
\text { culture } \\
\text { component }\end{array}$ & dpm & $\begin{array}{l}\text { Recovery } \\
\text { (dpm) }\end{array}$ & $\begin{array}{l}\text { Distribution of } \\
\text { recovered dpm } \\
\text { (\%) }\end{array}$ & $\begin{array}{c}\text { Absorbed } \\
\mathrm{dpm}^{a}\end{array}$ & $\begin{array}{l}\text { Distribution of } \\
\text { absorbed dpm } \\
(\%)\end{array}$ \\
\hline $\begin{array}{l}\text { Control } \\
\text { (input) }\end{array}$ & - & Glass & 98,635 & & & & \\
\hline Biopsy & 1 & $\begin{array}{l}\text { Glass } \\
\text { Tissue } \\
\text { Membrane } \\
\text { Medium }\end{array}$ & $\begin{array}{r}47,421 \\
41,097 \\
415 \\
0\end{array}$ & 88,933 & $\begin{array}{r}53.3 \\
46.2 \\
0.5 \\
0.0\end{array}$ & 41,512 & $\begin{array}{r}99.0 \\
1.0 \\
0.0\end{array}$ \\
\hline Biopsy & 2 & $\begin{array}{l}\text { Glass } \\
\text { Tissue } \\
\text { Membrane } \\
\text { Medium }\end{array}$ & $\begin{array}{r}23,493 \\
72,561 \\
2,195 \\
0\end{array}$ & 98,249 & $\begin{array}{r}23.9 \\
73.9 \\
2.2 \\
0.0\end{array}$ & 74,756 & $\begin{array}{r}97.1 \\
2.9 \\
0.0\end{array}$ \\
\hline Biopsy & 3 & $\begin{array}{l}\text { Glass } \\
\text { Tissue } \\
\text { Membrane } \\
\text { Medium }\end{array}$ & $\begin{array}{r}15,628 \\
69,321 \\
20,560 \\
0\end{array}$ & 105,509 & $\begin{array}{r}14.8 \\
65.7 \\
19.5 \\
0.0\end{array}$ & 89,881 & $\begin{array}{r}77.1 \\
22.9 \\
0.0\end{array}$ \\
\hline Biopsy & 4 & $\begin{array}{l}\text { Glass } \\
\text { Tissue } \\
\text { Membrane } \\
\text { Medium }\end{array}$ & $\begin{array}{r}12,827 \\
64,429 \\
27,643 \\
0\end{array}$ & 104,899 & $\begin{array}{r}12.2 \\
61.4 \\
26.4 \\
0.0\end{array}$ & 92,072 & $\begin{array}{r}70.0 \\
30.0 \\
0.0\end{array}$ \\
\hline
\end{tabular}

${ }^{a} \mathrm{dpm}$ (tissue) $+\mathrm{dpm}$ (membrane) $+\mathrm{dpm}($ medium $)=$ absorbed $\mathrm{dpm}$. 
on the glass decreased stepwise, from 98,635 to $12,827 \mathrm{dpm}$, during $4 \mathrm{hr}$ of exposure. The level of $\left[{ }^{14} \mathrm{C}\right] \mathrm{MBOCA}$ in the skin increased during the first $2 \mathrm{hr}$ to $72,561 \mathrm{dpm}$, and then decreased during the next $2 \mathrm{hr}$ to 64,429 . The level of $\left[{ }^{14} \mathrm{C}\right] \mathrm{MBOCA}$ on the supporting membrane filter increased over the $4 \mathrm{hr}$ of exposure to $27,643 \mathrm{dpm}$. The level of $\left[{ }^{14} \mathrm{C}\right] \mathrm{MBOCA}$ in the medium was negligible, suggesting that the carcinogen either needed more time to penetrate through the skin to the medium or was trapped on the membrane because of its insolubility in water (Glowinski et al., 1978). Recovery of applied $\left[{ }^{14} \mathrm{C}\right] \mathrm{MBOCA}$ was quantitative. This pattern of percutaneous absorption was reflected in the distribution (expressed in \%) of recovered $\left[{ }^{14} \mathrm{C}\right] \mathrm{MBOCA}$ in organ culture components: glass, tissue, membrane, and medium, and in the distribution (expressed in \%) of absorbed $\left[{ }^{14} \mathrm{C}\right] \mathrm{MBOCA}$ : in tissue, membrane, and medium. This experiment was repeated with four foreskins. A similar pattern of percutaneous absorption was found although the levels of MBOCA in organ culture components were different in each foreskin (see below).

Table 3 shows that there was relatively little variation in percutaneous absorption of $\left[{ }^{14} \mathrm{C}\right] \mathrm{MBOCA}$ in three biopsy samples taken from the foreskin of one patient and incubated at $37^{\circ} \mathrm{C} ; 9961-12,112 \mathrm{dpm}$ were found in membrane filters, and similar variations in ranges were found in glass, tissue, and medium. There was, however, considerably more variation in percutaneous absorption in punch biopsies from 10 patients (Table 4). The $\left[{ }^{14} \mathrm{C}\right] \mathrm{MBOCA}$ levels on membrane filters varied fivefold, from 6982 to $33,400 \mathrm{dpm}$, and wider ranges of distribution were also observed in the other organ culture components as well. This variability from individual to individual was like that observed for the uptake of various drugs in humans (Goldstein et al., 1974). In order to develop a better comparison of percutaneous absorption between individuals, levels of $\left[{ }^{14} \mathrm{C}\right] \mathrm{MBOCA}$ were recalculated as the percentage of absorbed $\left[{ }^{14} \mathrm{C}\right] \mathrm{MBOCA}$ (Table 4); $25.8-52.8 \%$ of the $\left[{ }^{14} \mathrm{C}\right] \mathrm{MBOCA}$ in tissues, membranes, and media was found in membranes.

Histologic observations of the biopsied foreskin showed that the epidermis was made up of well-differentiated epithelial cells (Fig. 3). The epithelium consisted of a columnar basal cell layer, several spinous cell layers of irregular polygon shape, a thin but distinct granulosum layer, and a thinly desquamating keratinosum layer. In certain areas of the dermis, glandular outgrowths resembling sebaceous glands were present (Fig. 4). These histological sections demonstrated the integrity of the neonatal foreskins used in this study: they were intact, the tissue was well differentiated, and the epidermis contained the normal, differentiated cell layers, from basal cells to stratum corneum.

Percutaneous absorption was dependent upon the temperature of incubation. Six punch biopsies were taken from one foreskin and set up in organ cultures. Three were incubated at $37^{\circ} \mathrm{C}$ and three were incubated on ice. The levels of $\left[{ }^{14} \mathrm{C}\right] \mathrm{MBOCA}$ in supporting membranes were markedly lower in organ cultures incubated at $0^{\circ} \mathrm{C}(398-1068 \mathrm{dpm})$ than at $37^{\circ} \mathrm{C}(9961-12,442 \mathrm{dpm})$ (Table 3). Radioautographs demonstrated that incubation at $0^{\circ} \mathrm{C}$ resulted in a sharp decrease in penetration of $\left[{ }^{14} \mathrm{C}\right] \mathrm{MBOCA}$ into the skin. Percutaneous absorption was limited to the stratum corneum and granular layers of the epidermis at $0^{\circ} \mathrm{C}$ (Fig. 5).

Radioautography demonstrated the physical presence of radiolabel throughout 
TABLE 3

Tfmperature Dfpendence of $\left[{ }^{14} \mathrm{C}\right]$ Mroc. A Permfation through Punch Biopsies from One HUMAN NEWBORN FORESKIN

\begin{tabular}{|c|c|c|c|c|}
\hline Sample & $\begin{array}{c}\text { Exposure } \\
\text { temperature } \\
\left({ }^{\circ} \mathrm{C}\right)\end{array}$ & $\begin{array}{l}\text { Exposure } \\
\text { (hr) }\end{array}$ & $\begin{array}{l}\text { Organ culture } \\
\text { component }\end{array}$ & $\mathrm{dpm}$ \\
\hline $\begin{array}{l}\text { Control } \\
\text { (input) }\end{array}$ & - & - & Glass & 108,988 \\
\hline Biopsy & 37 & 4 & $\begin{array}{l}\text { Glass } \\
\text { Tissue } \\
\text { Membrane } \\
\text { Medium }\end{array}$ & $\begin{array}{r}72,510 \\
20,322 \\
11,030 \\
410\end{array}$ \\
\hline Biopsy & 37 & 4 & $\begin{array}{l}\text { Glass } \\
\text { Tissue } \\
\text { Membrane } \\
\text { Medium }\end{array}$ & $\begin{array}{r}79,443 \\
15,929 \\
9,961 \\
474\end{array}$ \\
\hline Biopsy & 37 & 4 & $\begin{array}{l}\text { Glass } \\
\text { Tissue } \\
\text { Membrane } \\
\text { Medium }\end{array}$ & $\begin{array}{r}76,936 \\
18,189 \\
12,112 \\
298\end{array}$ \\
\hline Biopsy & 0 & 4 & $\begin{array}{l}\text { Glass } \\
\text { Tissue } \\
\text { Membrane } \\
\text { Medium }\end{array}$ & $\begin{array}{r}84,354 \\
9,501 \\
1,068 \\
275\end{array}$ \\
\hline Biopsy & 0 & 4 & $\begin{array}{l}\text { Glass } \\
\text { Tissue } \\
\text { Membrane } \\
\text { Medium }\end{array}$ & $\begin{array}{r}63,186 \\
42,330 \\
398 \\
149\end{array}$ \\
\hline Biopsy & 0 & 4 & $\begin{array}{l}\text { Glass } \\
\text { Tissue } \\
\text { Membrane } \\
\text { Medium }\end{array}$ & $\begin{array}{r}88,822 \\
14,796 \\
422 \\
219\end{array}$ \\
\hline
\end{tabular}

organ cultures incubated at $37^{\circ} \mathrm{C}$, with higher levels in all layers of the epidermis than in the dermis (Fig. 6).

Organ cultures were analyzed to determine if MBOCA was metabolized during absorption and permeation in our model system. When the radioactivity in supporting membranes was recovered and applied to a silica gel thin-layer chromatography plate, a brown spot appeared at the origin. After development, the brown spot remained at the origin, and three spots which had moved from the origin were detected by uv light: one spot was adjacent to the origin, one spot corresponded to MBOCA with an $R_{f}$ of 0.665 , and one spot had an $R_{f}$ of 0.880 \pm 0.011 . Sequential sectioning of the silica demonstrated that the spot corresponding to MBOCA contained $93.9 \pm 0.7 \%$ of the radioactivity on the plate. Less than $0.3 \%$ of the radioactivity was in areas corresponding to the other two uv-absorbing spots, and less than $1.6 \%$ of the total radioactivity on the plate remained at the origin. 


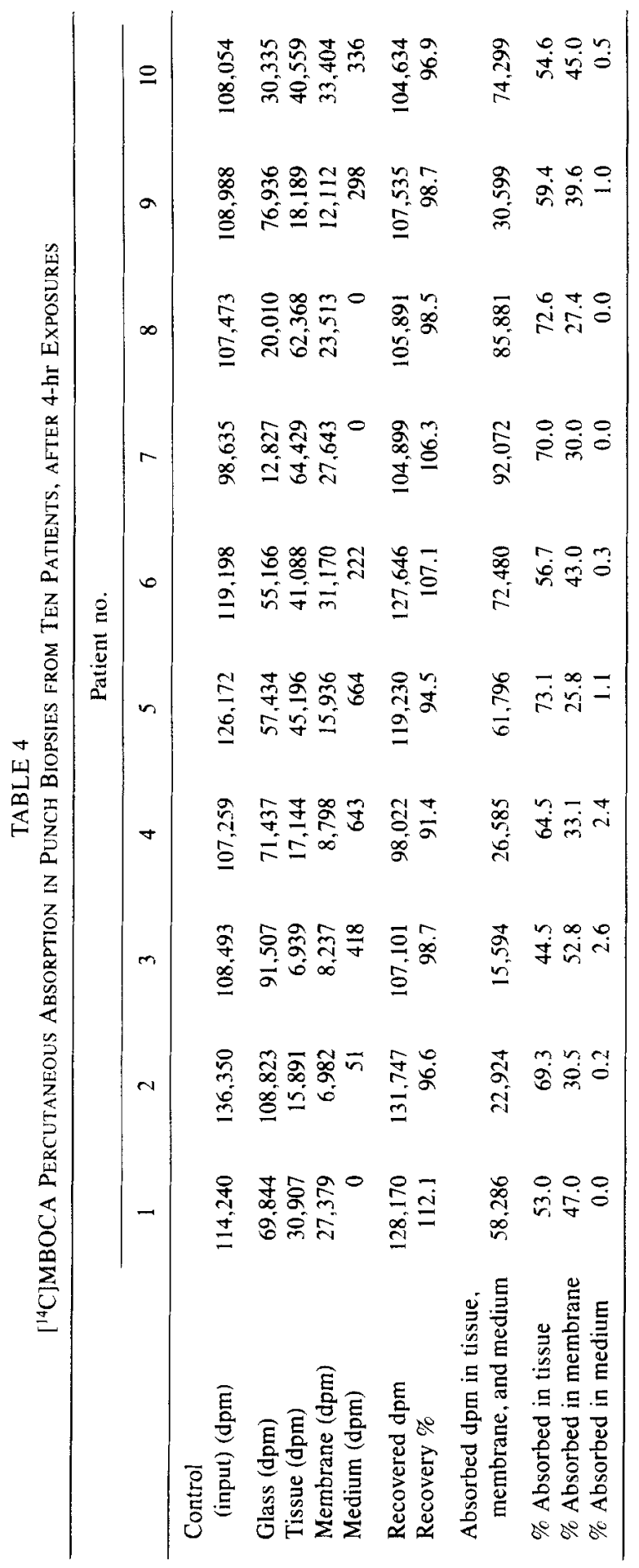



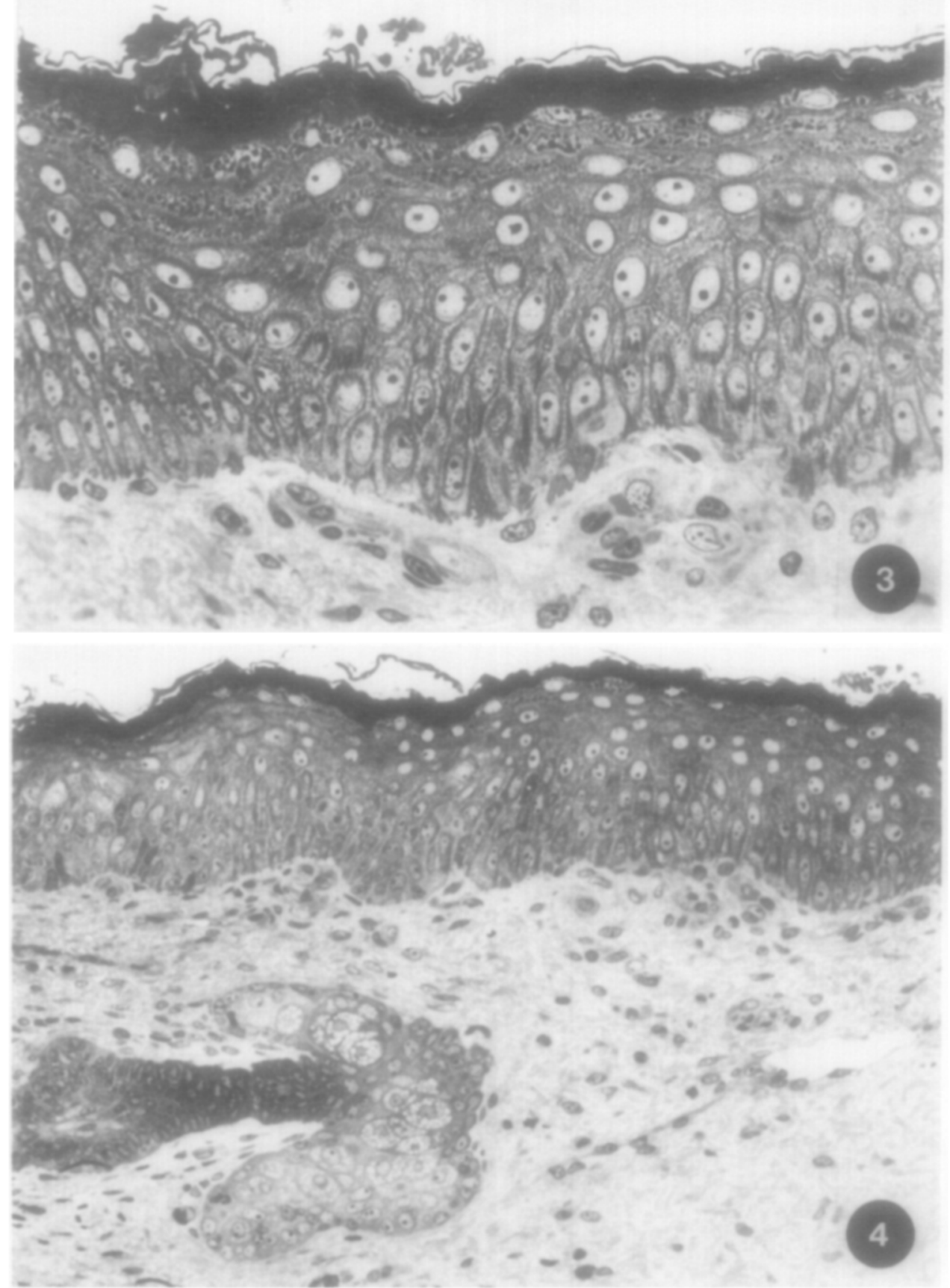

FIG. 3. Histological section (toluidine blue) of differentiated epidermis in human foreskin $(472 \times)$. FIG. 4. Histological section (toluidine blue) of epidermis and dermis in human foreskin $(230 \times)$. 

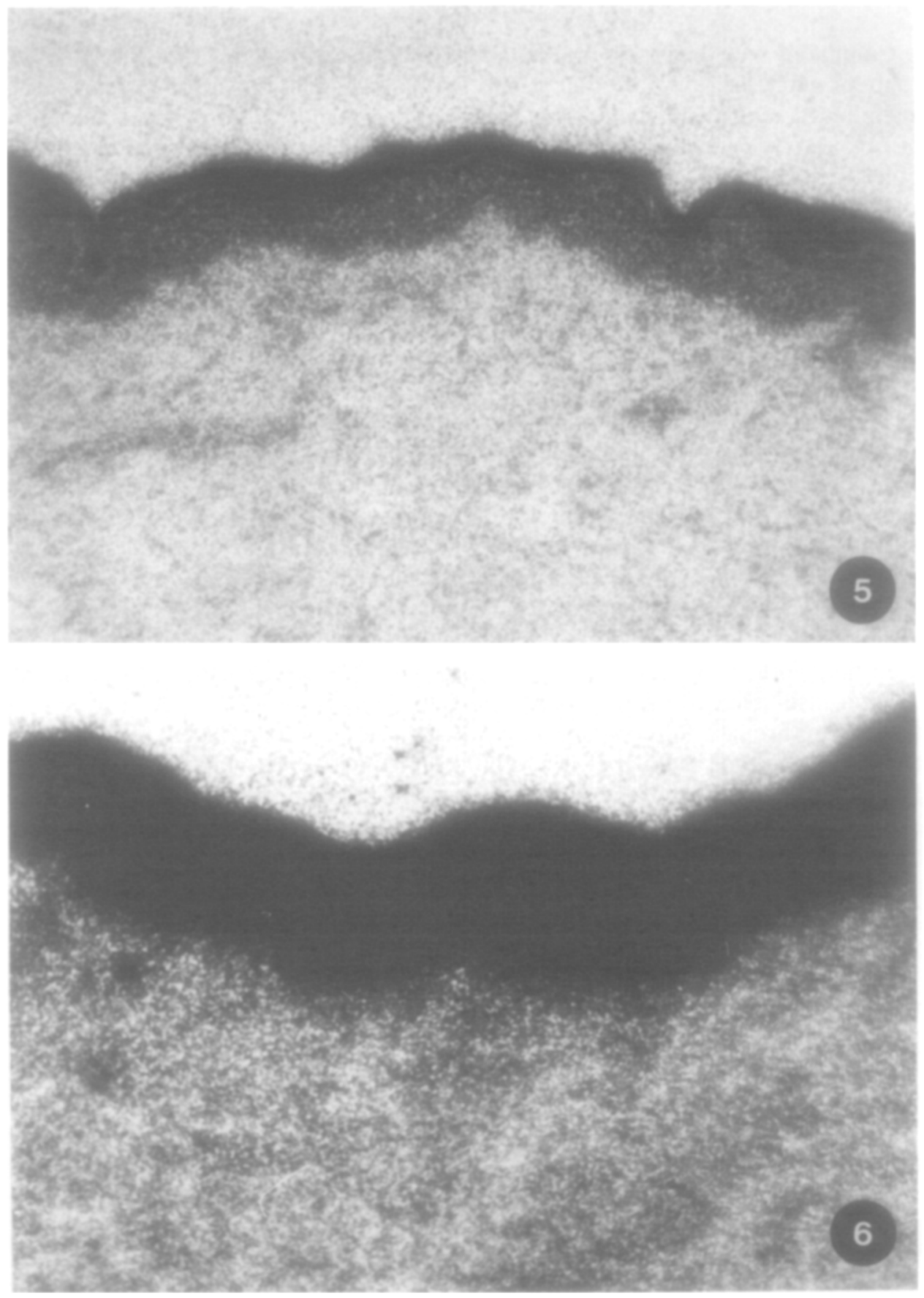

FIG. 5. Autoradiogram showing percutaneous absorption of $\left[{ }^{14} \mathrm{C}\right] \mathrm{MBOCA}$ in human foreskin incubated at $0^{\circ} \mathrm{C}(230 \times)$. The stratum corneum and granular layers in the epidermis were heavily labeled. the lower layers of the epidermis were labeled less, and the dermis was labeled least.

FIG. 6 Autoradiogram showing percutaneous absorption of $\left[{ }^{14} \mathrm{C}\right] \mathrm{MBOCA}$ through human foreskin incubated at $37^{\circ} \mathrm{C}(230 \times)$. All layers of the epidermis were heavily labeled, the dermis was less heavily labeled. 


\section{DISCUSSION}

Compared with ingestion and inhalation, skin absorption is the least studied route of entry for toxic substances into the body. Part of this neglect stems from a failure to recognize that disorders resulting from materials whose principal route of uptake is through the skin may be manifest on the long term and in organs other than skin, e.g., cancer.

Two systems have been used to study percutaneous absorption (for reviews, see Scheupflin, 1976; Idson, 1975; Wahlberg, 1973). One employed excised human skin, which was often a microtome section of stratum corneum, mounted in a diffusion chamber. The penetrant was applied to the stratum corneum and percutaneous absorption was measured by its appearance in a solution on the subdermal side. The other system employed topical application on cxperimental subjects, and measured the appearance of penetrant in blood or urine. These systems have contributed greatly to current concepts of percutaneous absorption. However, the appropriateness of using microtome sections rather than intact skin in diffusion chamber studies has been suspect, although criticisms were muted because the stratum corneum was considered to be the main barrier to percutaneous absorption. Also, the diffusion chamber was not amenable for studying dry, contact exposures, which must represent a large number of environmental situations. In topical applications, the physiological distance from the site of application to appearance in blood or urine was often too great for studying percutaneous events.

In this work, a system was developed to measure percutaneous absorption of a water-insoluble carcinogen through human skin. Dry $\left[{ }^{14} \mathrm{C}\right] \mathrm{MBOCA}$-bearing surfaces were brought into contact with organ cultures prepared from foreskin and the appearance of radiolabel in culture components was monitored with time. Radiolabel was found on the supporting membrane in contact with the subdermal side of the tissue within $3 \mathrm{hr}$ (Table 2). Radioautographs demonstrated the physical presence of radiolabel in the tissue (Fig. 6), and thin-layer chromatography revealed that the radiolabel recovered from the supporting membrane was MBOCA. Taken together, these findings support our conclusion that MBOCA passed quickly through the skin without being metabolized.

The variation in percutaneous absorption of MBOCA between biopsy samples taken from one person was relatively small (Table 3 ) compared with the variation between biopsy samples taken from 10 individuals (Table 4). Perhaps this result was not completely unexpected, since the uptake of drugs in humans is known to vary within a population (Goldstein et al., 1974).

An estimate of risk due to skin exposure was calculated from percutaneous absorption of $\left[{ }^{14} \mathrm{C}\right] \mathrm{MBOCA}$ in organ cultures. Twenty microliters of an ethanol solution with $100,000 \mathrm{dpm}$ of $\left[{ }^{14} \mathrm{C}\right] \mathrm{MBOCA}$ contained $1.1 \mu \mathrm{g}$ MBOCA; this amount was deposited on each 7-mm square coverslip and allowed to dry. Since the surface of a 6-mm round punch biopsy is $28.3 \mathrm{~mm}^{2}$ and the area of the $7-\mathrm{mm}$ square coverslip is $49 \mathrm{~mm}^{2}$, only $58 \%$ or $0.64 \mu \mathrm{g}$ of the MBOCA was in direct contact with skin when the coverglass was placed on punch biopsy, assuming a uniformly spread layer of isotope. This translates to a level of exposure to MBOCA in organ cultures of $2.24 \mu \mathrm{g} \mathrm{MBOCA} / \mathrm{cm}^{2}$ of skin.

Harger (1979) calculated that a $15-\mathrm{kg}, 4$ year old child playing in garden soil, 
containing $55 \mathrm{ppm}$ MBOCA, was covered with a fine film of dust with $1.04 \mathrm{mg}$ MBOCA spread over a body area of $6800 \mathrm{~cm}^{2}$, or $0.15 \mu \mathrm{g} \mathrm{MBOCA} / \mathrm{cm}^{2}$ of skin. Thus, our organ cultures were exposed to $14.9 \times$ Harger's estimate for the "dirty child." The skin in thesc expcriments was exposed to an equivalent soil content of $821 \mathrm{ppm}$.

The minimum risk from exposure to MBOCA was estimated by using the lowest value for MBOCA passing through a 6-mm biopsy in $4 \mathrm{hr}$, which was $6982 \mathrm{dpm}$ (Table 4), and does not include the MBOCA that was on or in the skin. This was equivalent to $0.27 \mu \mathrm{g}$ of MBOCA penetrating each square centimeter of skin. If neonatal foreskin is assumed to be representative of the body skin of a 4-yearold child during a 4-hr exposure to soil contaminated at $821 \mathrm{ppm} \mathrm{MBOCA}$, and assuming that percutaneous absorption of MBOCA is dose dependent, then 123 $\mu \mathrm{g}$ MBOCA would have penetrated through the total skin from soil containing 55 ppm MBOCA. This is $143 \times$ greater than the lowest dose in the analysis prepared by Hartung (1980). Therefore, the risk due to skin exposure is potentially far greater and more insidious than that due to ingestion.

This model provides an estimate of risk under one set of defined conditions. Since percutaneous absorption depends upon age, sex, and body region of skin (Wahlberg, 1975), the selection of a practical and generally acceptable representative skin sample is difficult, if not impossible. Neonatal foreskins were selected for our studies because of their availability, and because they were restricted in age, sex and body region. Newborn skin is thought to be more permeable than adult skin because the stratum corneum is thinner in newborn skin and presents less of a barrier to penetration (Scheuplfin, 1976; Idson, 1975; Wahlberg, 1973). This may be a minor criticism in our studies, since the stratum corneum does not appear to be a major barrier for MBOCA. It should be pointed out that the epidermis of newborn foreskin has all the differentiated layers of mature skin (Fig. 4). Radioautographs prepared from organ cultures incubated at $37^{\circ} \mathrm{C}$, whereupon percutaneous absorption proceeded rapidly, showed that MBOCA labeled the stratum corneum and all other layers of the epidermis heavily (Fig. 6). Radioautographs prepared from organ cultures incubated at $0^{\circ} \mathrm{C}$, whereupon percutaneous absorption decreased dramatically, showed that MBOCA was concentrated in the stratum corneum and granular layers of the epidermis but labeled the lower layers of the epidermis less heavily (Fig. 5). Our assessment may also be criticized for the propriety of comparing skin absorption with ingestion. Recent work, however, suggests that they may not be so disparate since the routes and kinetics of excretion were similar when MBOCA was administered orally, intravenously, and by skin painting to rats and dogs; tissue distributions resulting from these routes of administration also appeared to be similar (MTSCC, 1982).

Overall, the two orders of magnitude increase in risk derived from these skin absorption studies, compared with ingestion, speaks to the concern for humans exposed to MBOCA.

\section{ACKNOWLEDGMENT}

The authors are indebted to the staff at the Nursery, Women's Hospital, University Hospital, University of Michigan, Ann Arbor, Michigan, for securing foreskins for this study. 


\section{REFERENCES}

Glowinski, I. B., Radtke, H. E., and Weber, W. W. (1978). Genetic variation and $N$-acetylation of carcinogenic arylamines by human and rabbit liver. Mol. Pharmacol. 11, 940-949.

Goldstein, A., Aronow, L., and Kaplan, S. M. (1974). "Principles of Drug Action: The Basis of Pharmacology," 2nd. ed. Wiley, New York.

Harger, J. R. E. (1979). "A Model for the Determination of an Action Level for Removal of Curene Contaminated Soil." Michigan Toxic Substances Control Commission.

Hartung, R. (1980). "Risk Assessment for 4,4'-Methylene-bis[2-chloroaniline]." Michigan Toxic Substances Control Commission.

Idson, B. (1975). Percutaneous absorption. J. Pharm. Sci. 64, 901-924.

Kommineni, C., Groth, D. H., Frockt, I. H., Voelker, R. W., and Stanovick, R. P. (1979). Determination of the tumorigenic potential of methylene-bis-ortho-chloroaniline. J. Environ. Pathol. Toxicol. 2, 149-171.

Linch, A. L., O'Connor, G. B., Barnes, J. R., Killian, A. S., Jr., and Neeld, W. E., Jr. (1971). Methylene-bis-ortho-chloroaniline (MOCA (Registered trademark)): Evaluation of hazards and exposure control. Amer. Ind. Hyg. Assoc. J. 32, 802-819.

McCann, J., Choi, E., Yamasaki, E., and Ames, B. N. (1975). Detection of carcinogens as mutagens in the Salmonella/microsome test: Assay of 300 chemicals. Proc. Nat. Acad. Sci. USA 72, 51355139.

Messier, B., and Leblond, C. P. (1957). Preparation of coated radioautographs by dipping sections in fluid emulsion. Proc. Soc. Exp. Biol. Med. 96, 7-10.

Michigan Department of Natural Resources (1979). "Curene Contamination in Adrian. Summary of Investigations to July $25,1979 . "$

Michigan Toxic Substance Control Commission (1982). "Summary Report of Meeting Featuring Research Sponsored by the Commission (March 10, 1982)."

Occupational Safety and Health Administration (OSHA) (1978). "Report of the Advisory Committee on Cutaneous Hazards." U.S. Department of Labor.

Russfield, A. B., Homburger, F., Bogen, E., Van Dongen, C. D., Weisburger, E. K., and Weisburger, J. H. (1975). The carcinogenic effect of 4,4'-methylene-bis(2-chloroaniline) in mice and rats. Toxicol. Appl. Pharmacol. 31, 47-54.

Scheupflin, R. J. (1976). Percutaneous absorption after twenty-five years: Or "old wine in new wineskins." J. Invest. Dermatol. 67, 31-38.

Stula, E. F., Barnes, J., Sherman, H., Reinhardt, C. F., and Zapp, J. A., Jr. (1978). Urinary bladder tumors in dogs from 4,4'-methylene-bis(2-chloroaniline) (MOCA). J. Environ. Pathol. Toxicol. 1, $31-50$.

Wahlberg, J. E. (1973). Percutaneous absorption. Curr. Prob. Dermatol. 5, 1-36.

Wahlberg, J. E. (1975). Percutaneous absorption. J. Pharm. Sci. 64, 901-924.

Wang, C. L. (1979). Occupational skin disease continues to plague industry. Monthly Labor Rev. Feb, $17-22$. 